\title{
IMPROVING KNOWLEDGE AND SKILLS RETENTION FOR FUTURE TEACHERS IN TECHNICAL AND VOCATIONAL EDUCATION THROUGH PROJECT-BASED LEARNING (PJBL)
}

\author{
Muhammad Khair Noordin*, Dayana Farzeeha Ali, Ahmad Nabil Md Nasir, Mohamad Rasidi Pairan, \\ Aini Najwa Azmi \\ School of Education, Faculty of Social Science and Humanities, Universiti Teknologi Malaysia \\ *mdkhair@utm.my
}

\begin{abstract}
Due to the existence of Vocational Colleges (KV), the teachers' teaching criteria in KV have also undergone a change. Not only teachers need to have theoretical knowledge only, but teachers need to have high set of skills in doing practical work. It is therefore a priority for these future teachers to master and remember what they have learned in the university because they are able to help them when they want to convey to students in KV later. Therefore, lecturers need to use appropriate approaches to ensure that students understand a lesson, so they can remember easily and longer namely using Project Based Learning (PjBL). Hence, the main objective of this study is to look into the impact of PJBL in improving the retention of knowledge and skills of students who are also the future teachers in KV. The sample of this study consisted of two groups of fourth year students who attended the Education and Technology (Mechanical Engineering) courses. This study used quasi experimental study design in which the Pretest- Posttest design was used to look at the effects of PjBL in term of memory retention period of the students. Fully qualitative method was used in which the students in both group were observed and interviewed in order to gain additional findings. The findings show that the students in the experimental group were having improved knowledge and skills retention as $81.8 \%$ obtained score above 80 in the Posttest, whereas only $14.3 \%$ of the students in the control group obtained score above 80 . The findings also showed that the main factor that improved their knowledge and skills retention was the requirement for the students to use problem solving skills during the project works. Thus, $\mathrm{PjBL}$ is a suitable learning method to improve the knowledge and skills retentions for the students.
\end{abstract}

Keywords: Knowledge Retention, TVE, Vocational College

\section{INTRODUCTION}

Technical and Vocational Education (PTV) is one of the education streams in Malaysia that caught attention from the government recently; and more effort is given in order to develop PTV effectively. Previously, PTV is seen as a second-class education, it is now able to compete with mainstream education. This awareness is realized by the government when they are believed that PTV is able to help the country to achieve the status of developed countries. Through PTV, many skilled and semiskilled workers can be created and thus it can reduce the country's dependence on foreign workers (Mohd Yusof, 2014). In addition, many job opportunities that are available are based on skills. Thus, the government has transformed the PTV system as an alternative to adapt the globalization changes. The Ministry of Education has played a role in transformation in the field of PTV through Vocational and Technical Transformation, where almost all technical and vocational schools across the country are replaced with Vocational College (KV). The most major changes are not only the name, but also involves changes in curriculum, assessment and certification. Former Director of Technical and Vocational Education Division (BPTV) from Ministry of Education, Dato Ahmad Tajudin Jab said that the transformations are involved the technical and vocational curriculum, duration of study, certification recognition, instructors, infrastructure and most important is to re-branding the vocational secondary schools to Vocational College (Jamaliah, 2014). 
As a result, the number of PTV institutions in Malaysia has increased in Malaysia and has led to more teachers trained in the Technical and Vocational field. The increment of the number of teachers is crucial as there is an increasing number of students who are to follow the technical and vocational trends and the availability of technical subjects offered at boarding schools and selected daily schools students is increased due to changes of the perception of the community, parents and students themselves on the importance of vocational and technical skills and it is crucial to fulfill the job demands by employers which is related to the national economic development. Therefore, a specific training must be given to the future teachers to ensure that they have the appropriate skills and knowledge. These skills and knowledge are important to make sure the teaching and learning process run smoothly between teachers and the KV's students.

As we know that teachers are the most important asset as they will produce the various workforce and experts required by the nation Yoto (2017). They also give their services to the whole people of the nation. They are the implementers of all the policies and goals set by the government through the Ministry of Higher Education and Ministry of Education Malaysia. Simultaneously, the education program for future teachers is important for supplying future teachers with the skills needed by a teacher to enable them to teach more effectively. A lot of changes need to be done in the future teacher education programs including teaching, management, research and evaluation. Generally, the ability to acquire first-class human capital must be obtained from the excellent teachers. To achieve that, it must be the starting point of the education / training program/ supplied to the teacher. As potential teachers who will teach at $\mathrm{KV}$, practical training while at university must be given to enable them to teach the element of skills (Jamaliah, 2014). In addition, they also need to evolve the theory behind these practices to enable them to explain to the students.

As a teacher, the knowledge and skills learned must be devoted to the students in an effective way to ensure that the knowledge can be absorbed by the students. This is because the teachers are responsible in providing the best to their students and subsequently producing the skilled students required by the nation (Bajrami, 2016). Therefore, the teachers need to have sufficient knowledge and skills and should remember what they have learned while at university. This is important because teachers need to first understand what they have learned before communicating to the students. In addition, it also ensures the quality of knowledge and skills available to the teacher as well as ensuring that the knowledge and skills delivered by the teacher are correct. Hence, it is the responsibility of the university to ensure the education and teaching techniques or systems for future teachers are effective in ensuring that they can maintain the knowledge and skills they have learned.

\section{PROBLEM BACKGROUND}

Recently, the field of PTV is an area that gets more attention from most people. This is because PTV can be a key for Malaysia to be a developed country (Paryono, 2017). More efforts have been done by the state in ensuring the PTV is able to grow rapidly and get a response from a multiracial society. Various changes have been made to the old system of vocational and technical schools as now $\mathrm{KV}$ is able to award Malaysia's Vocational Diploma status to its graduates. In addition, KV graduates also will be awarded with the Malaysian Skills Certificate (SKM) and Malaysian Vocational Certificate which can show an overview of the skill level possessed by KV graduates. Due to these changes, the teachers' teaching criteria in KV have also undergone a change. Not only teachers need to have theoretical knowledge, but teachers need to have appropriate skills in doing practical work. In addition, prospective teachers are required to have Malaysian Skill Certificate at least level 3 to qualify them to teach in KV.

As potential teachers, they need to ensure that they have enough skills and knowledge before enabling them to teach in KV. Therefore, it is important for potential teachers to master and remember what they have learned when they are at university. These can help them while teaching in the class. However, there are several problems faced by potential teachers when they were trainee teachers before and when they are appointed teachers in one KV. Looking into this problem in the context of PTV, a preliminary study was conducted on 10 students who had been trainees in KV around Peninsular Malaysia during Teaching Practice. Based on the interviews, 8 out of 10 students informed that they were less skilled in the subjects they needed to teach as a trainee teacher. While all of them have studied the subject before becoming a trainee teacher, they say they are hard to recall what they have learned especially related to theory. While 
on technical and practical aspects, most of them said that they can only remember less than $50 \%$ of what was being taught and most of what they remembered the basic only. Among the main causes that cause this problem is the reliance on group members to solve the problem. Simultaneously, the distribution of group work by division also resulted in only a fraction of the entire project. Additionally, they often rely on notes whenever they make practical or even projects. Six of them also said they only memorized what they learned without understanding the theories related to their practices. However, all respondents agreed that knowledge and skills from the university were very useful to them in the teaching process.

Based on preliminary study, it is undeniable that teachers need the knowledge and skills learned at universities to last longer in their memory. The retention period of knowledge and skills in a person's memory depends on the way they learn one thing. Based on that, the retention period of knowledge and skills will be enhanced through practical work, where students can apply what they have learned. Based on Custers (2010), students tend to forget about $25 \%$ and $35 \%$ of what they have learned over the course of a year and will forget about $50 \%$ over the next year. This is an issue that needs to be addressed by those who educate students who will be the future teachers which is the university itself. To enable these students to remember easier and longer, the lecturer should ensure that students understand what they have learned in the lecture. However, there are many students in the university who tend to remember what they learned without understanding the concept of the lesson. Therefore, lecturers should use appropriate approaches to ensure that students can understand the lesson, so they can remember easily and longer (Klemm, 2007). Klemm also added that these students were not able to apply what they learned if they did not understand what they learned. This is in line with the quoted words of Conficius that is, "Tell me and I will forget, show me and I will remember; engage me then I will understand".

The two elements contain in the above words are demonstration and hand-on elements which able to enable students to remember and understand. This is in line with the study conducted by Buddelmeyer (1995) where he has seen the difference in memory retention for two special education group students who have seen demonstrations of practical training from instructors and students who have seen the demonstrations and made practical exercises using their own hands. His findings show that special education students exposed to demos are just a few of the demonstration steps against students who see demonstrations while doing their own hands. This study proved crucial to demonstrate to students the understanding of them and to be accompanied by practical work to strengthen their knowledge.

\section{PROJECT-BASED LEARNING (PJBL)}

Project-Based Learning (PJBL) is a pedagogical approach inspired by John Dewey, an American philosopher who emphasizes the importance of hands-on experience or learning and allows students to solve open-ended and complexes problems, and to give students the opportunity to apply their knowledge. PjBL is seen as a teaching method that can provide both students the experience they need to remember and understand the lessons. Through PJBL, students are required to create a knowledgebased practical project that they have learned. The purpose of this study is to examine the effectiveness of PjBL in extending the students' knowledge period, which are the future PTV teachers. Based on a study conducted by Muhammad Khair et al. (2011), PjBL has the following features:

1. $\mathrm{PjBL}$ is the process of application of knowledge - students apply what they have learned (theory) into practice - hands-on approach.

2. Integration of knowledge - interdisciplinary learning

3. Problems are based on real world problems - problems are relevant and contextual. It is in the process of struggling with actual problems that students learn content and critical thinking skills

4. End products will drive the students to shape and describe the whole production, planning and evaluation process.

5. Emphasizes on the development of students' skill to design and carry out project

6. $\mathrm{PjBL}$ is learner-centered - learners are progressively given more responsibility for their education and become increasingly independent of the teacher for their education

7. Learning process focuses on the production of model

8. Success of the PjBL is evaluated through skills obtained during the process of production of the model.

9. Provides real world experience to students

10. Teachers or lecturers act as facilitator who give them guidance and help. 
11. Emphasizes on higher level thinking skills

12. Students develop and formulate their own designs and experiments

13. Students work on the project as a group

14. Consumes a lot of time to finish the product

15. It is carried out in risk-free environment where it provides positive feedback and allows students to make their choice

However, the characteristics of PjBL implemented in this study do not cover all the following characteristics as there are many constraint factors that prevent PjBL from executing perfectly. Therefore, the implementation of the PJBL implemented in this study is based on the features mentioned by Thomas (2000) namely:

1. Centrality: project-based learning projects are central, not peripheral to the curriculum

2. Driving question: project-based learning projects are focused on questions or problems that "drive" students to encounter the central concepts and principles of a discipline

3. Constructive investigation: projects involve students in a constructive investigation

4. Autonomy: projects are student-driven to some significant degree

5. Realism: projects are realistic, not school-like.

Implementation of $\mathrm{PjBL}$ in this study refers to the definition of PjBL itself where it is a learning approach made around the project and the project must be open ended, where the solution can use various methods and not unique. Through PjBL, students have been exposed to various projects that require them to think critically and creatively as well as they can apply and integrate the knowledge they have learned.

\section{METHODOLOGY}

This study used an experimental-quasi research design, where Pre-Test and Post Test are used to identify the effects of PjBL on the memory retention period of the students. This research has used two groups, which are control groups and experimental groups. The control group would not be exposed to treatment which is the $\mathrm{PjBL}$, while the experimental group has been exposed to PjBL for three months. The students from both groups went through the same subject which is The Basic of Robotic and Mechatronic in their sixth semester. This subject is a practical subject where students are required to make six practical tasks, two mini projects and one final project. Normally, practical learning is done by providing practical manuals that require them to follow the manual. Mini projects are combining several topics and students had been given a simple manual, which is not as detailed as the previous practical. Getting harder in the final project, students only received instructions to build the project without any manuals. This teaching method will be applied to the control group for this study. On the other hand, for the experimental group, a Project-Based Learning (PjBL) approach was introduced where as they were needed to make three practical tasks, four mini projects and one final project. The practices of experimental group are different where the students only received a very short manual as their guidance. There are also differences in their mini projects where they were organized according to difficulty levels. However, the mini project is structured, so that every project is relevant and able to encourage students to re-apply what they have learned until the final mini project. The mini project is divided into group (two tasks) and individual (two tasks). The final project for the experimental group was the same as the control group, but the level of difficulty has been increased where it requires the students to critically and creatively think. In addition, the students were in smaller group sizes than the control groups.

Based on the research design, pre-test is required for both groups as it is a test of their initial understanding of the subject and to ensure that the achievement of students in both groups are the same. Pre-test and post-test instruments are the same as they were related to the Basics of Robotic and Mechatronic subject. It contains fifteen objective questions, two subjective questions and 1 practical task where the students were given an hour to answer the whole questions. Pre-test was given during the first week of semester while post-test was given in the 12th week of the semester.

In this study, researchers use quantitative and qualitative methods to obtain data from both groups. The quantitative methods are the pre-test and post-test given to both groups. Subsequently, qualitative data was collected using two methods which were interviews and observations. Observation was done to 
three groups of students from both experimental and control groups. A checklist was developed as the observation instrument with aspects of Teamwork, Group Discussion, Notes Usage and Problemsolving. For interviews, nine students from both groups were randomly selected for the interview process where five were from the control group and four were from the experimental group. A semistructured interview protocol was conducted to obtain in-depth data on the level of knowledge retention and skills as well as the appropriate learning criteria to enhance the level of knowledge retention and skills.

\section{RESULTS AND ANALYSIS}

To analyze the quantitative findings of the pre-test and post-test, inferential analysis which is independent t-test is used to see the mean difference between the two groups. Table 1 shows the mean value of both groups for the test. The t-test resulted no significant difference between the mean score of both groups $(p>0.05)$. It proved that both groups had the same level of knowledge before the intervention took place.

Table 1. T-test value for pre-test between control and experimental groups

\begin{tabular}{|c|c|c|}
\hline Group & Min & Sig. \\
\hline Control & 2.00 & \multirow{2}{*}{0.682} \\
\cline { 1 - 2 } Experimental & 2.00 & \\
\hline
\end{tabular}

For post-test min values (Table 2), the results from the t-test showed difference results compared to the test where there were significant differences between the two groups $(p<0.05)$. The experimental group min is higher than the control group, so it is proven that experimental groups have performed better in their tests.

Table 2. T-test value for post-test between control and experimental groups

\begin{tabular}{|c|c|c|}
\hline Group & Min & Sig. \\
\hline Control & 67.59 & \multirow{2}{*}{0.01} \\
\cline { 1 - 2 } Experimental & 84.10 & \\
\hline
\end{tabular}

For further analysis purposes, t-test is also conducted on each section (objective, subjective and practical) in the post-test. Based on the analysis, the objective part showed a significant difference $(\mathrm{p}<$ 0.05 ) and it proved that the experimental group performed well against the control group.

Table 3. T-test value for post-test (objectives questions) between control and experimental groups

\begin{tabular}{|c|c|c|}
\hline Group & Min & Sig. \\
\hline Control & 9.91 & \multirow{2}{*}{0.03} \\
\cline { 1 - 2 } Experimental & 12.52 & \\
\hline
\end{tabular}

Significant differences are also found in the subjective and practical parts which resulted the values of 0.00 and $0.01(\mathrm{p}<0.05)$ respectively in the post-test. It proved that the experimental group performed well against the control group.

Table 4. T-test value for post-test (subjective questions) between control and experimental groups 


\begin{tabular}{|c|c|c|}
\hline Group & Min & Sig. \\
\hline Control & 30.36 & 0.00 \\
\cline { 1 - 2 } Experimental & 37.86 & \\
\hline
\end{tabular}

Table 5. T-test value for post-test (practical questions) between control and experimental groups

\begin{tabular}{|c|c|c|}
\hline Group & Min & Sig. \\
\hline Control & 27.32 & \multirow{2}{*}{0.01} \\
\cline { 1 - 2 } Experimental & 33.71 & \\
\hline
\end{tabular}

For qualitative data, it was analyzed using thematically. Based on the observations that was carried out to the control group and the experimental group of students, the theme as can be seen in Table 6 was generated and the observation data was recorded in three phases which were early, intermediate and final phases to see any changes to the students throughout the learning process.

Table 6. Themes generated from observations

\begin{tabular}{|c|c|c|c|}
\hline Theme & Phase & Control & Experimental \\
\hline \multirow{3}{*}{$\begin{array}{c}\text { Notes } \\
\text { dependence }\end{array}$} & Early & Too depends on notes. & Too depends on notes. \\
\hline & Intermediate & Too depends on notes. & Still depends on notes but decreases. \\
\hline & Final & $\begin{array}{l}\text { Still depends on notes but } \\
\text { decreases. }\end{array}$ & $\begin{array}{l}\text { No more notes dependence but only } \\
\text { discussion among team members. }\end{array}$ \\
\hline \multirow[t]{3}{*}{$\begin{array}{l}\text { Teachers } \\
\text { Dependence }\end{array}$} & Early & $\begin{array}{l}\text { Need guidance from } \\
\text { teachers even for basic } \\
\text { task. }\end{array}$ & $\begin{array}{l}\text { Need guidance from teachers even for } \\
\text { basic task. }\end{array}$ \\
\hline & Intermediate & $\begin{array}{l}\text { Need guidance from } \\
\text { teachers even for basic } \\
\text { task. }\end{array}$ & $\begin{array}{l}\text { Need guidance from teachers but they } \\
\text { start asking harder questions. }\end{array}$ \\
\hline & Final & $\begin{array}{l}\text { Need guidance and } \\
\text { explanations from } \\
\text { teachers even for basic } \\
\text { task. }\end{array}$ & $\begin{array}{l}\text { Only ask questions that hard to } \\
\text { understand. }\end{array}$ \\
\hline \multirow[t]{3}{*}{$\begin{array}{c}\text { Team } \\
\text { member } \\
\text { dependence }\end{array}$} & Early & $\begin{array}{l}\text { Too depends on team } \\
\text { members to solve } \\
\text { problems. }\end{array}$ & $\begin{array}{l}\text { Too depends on team members to } \\
\text { solve problems. }\end{array}$ \\
\hline & Intermediate & $\begin{array}{l}\text { Too depends on team } \\
\text { members to solve } \\
\text { problems. }\end{array}$ & $\begin{array}{l}\text { Some of them still depends on team } \\
\text { members to solve problems. }\end{array}$ \\
\hline & Final & $\begin{array}{l}\text { Some of them still } \\
\text { depends on team } \\
\text { members to solve } \\
\text { problems. }\end{array}$ & Able to solve problems independently. \\
\hline $\begin{array}{l}\text { Group } \\
\text { Discussion }\end{array}$ & Early & $\begin{array}{l}\text { Able to solve problem } \\
\text { together in a long time. }\end{array}$ & $\begin{array}{l}\text { Able to solve problem together in a } \\
\text { long time. }\end{array}$ \\
\hline
\end{tabular}


The Turkish Online Journal of Design, Art and Communication - TOJDAC

ISSN: 2146-5193, September 2018 Special Edition, p.769-780

\begin{tabular}{|c|c|c|c|}
\hline & Intermediate & $\begin{array}{l}\text { Still need long time to } \\
\text { solve problems together. }\end{array}$ & $\begin{array}{l}\text { Able to delegate tasks among team } \\
\text { members and able to solve more than } \\
\text { one problems in a time. }\end{array}$ \\
\hline & Final & $\begin{array}{l}\text { Still need long time to } \\
\text { solve problems together. }\end{array}$ & $\begin{array}{l}\text { Each team member has his/her own } \\
\text { ideas in how to solve the problems } \\
\text { and discuss together. }\end{array}$ \\
\hline \multirow{3}{*}{$\begin{array}{l}\text { Able to give } \\
\text { suggestions } \\
\text { in the group } \\
\text { to solve } \\
\text { problems }\end{array}$} & Early & $\begin{array}{l}\text { Able to give suggestion } \\
\text { after referring to the notes } \\
\text { and teacher. }\end{array}$ & $\begin{array}{l}\text { Able to give suggestion after referring } \\
\text { to the notes and teacher. }\end{array}$ \\
\hline & Intermediate & $\begin{array}{l}\text { Able to give suggestion } \\
\text { after referring to the notes } \\
\text { and teacher. }\end{array}$ & $\begin{array}{l}\text { Able to give suggestion after referring } \\
\text { only to the notes. }\end{array}$ \\
\hline & Final & $\begin{array}{l}\text { Able to give suggestion } \\
\text { after referring to the notes } \\
\text { and teacher. }\end{array}$ & $\begin{array}{l}\text { Able to give suggestion after without } \\
\text { referring to the notes and teacher. }\end{array}$ \\
\hline \multirow[t]{3}{*}{$\begin{array}{l}\text { Able to relate } \\
\text { theory and } \\
\text { practice in a } \\
\text { group work }\end{array}$} & Early & $\begin{array}{l}\text { Hard to apply theory to } \\
\text { practice }\end{array}$ & $\begin{array}{l}\text { Still hard to apply theory to practice } \\
\text { while doing practical task and mini } \\
\text { project }\end{array}$ \\
\hline & Intermediate & $\begin{array}{l}\text { Still hard to apply theory } \\
\text { to practice while doing } \\
\text { mini project }\end{array}$ & $\begin{array}{l}\text { Able to relate theory with the mini } \\
\text { project they have done. }\end{array}$ \\
\hline & Final & $\begin{array}{l}\text { Still hard to apply theory } \\
\text { to practice while doing } \\
\text { mini project }\end{array}$ & $\begin{array}{l}\text { Able to apply theory they have } \\
\text { learned effectively while doing mini } \\
\text { project. }\end{array}$ \\
\hline
\end{tabular}

Based on analysis made from the observation, students from the experimental group experienced significant improvement in each phase compared to students from the control group. Looking in the aspect of knowledge and skills retention, students from the experimental group are able to remember what they are learning better where they do not need to refer to notes often while doing practical tasks and mini projects. Meanwhile, through the interviews, several themes have been obtained from both groups as shown in Table 7.

Table 7. Themes generated from interviews

\begin{tabular}{|c|c|c|}
\hline Theme & Group & List of Coding \\
\hline \multirow[t]{2}{*}{$\begin{array}{l}\text { Students' perception on } \\
\text { the difficulty level of } \\
\text { the practical task }\end{array}$} & Control & $\begin{array}{l}\text { - Easy } \\
\text { - Only follow the procedure } \\
\text { - No need to think much } \\
\text { - Easy to be done } \\
\text { - No need to refer notes }\end{array}$ \\
\hline & Experimental & $\begin{array}{l}\text { - Slightly difficult } \\
\text { - Need to refer to the notes } \\
\text { - Need to plan before starting the practical task } \\
\text { - Still need to refer to the teacher }\end{array}$ \\
\hline
\end{tabular}




\begin{tabular}{|c|c|c|}
\hline \multirow[t]{2}{*}{$\begin{array}{l}\text { Students' perception on } \\
\text { the difficulty level of } \\
\text { the mini project }\end{array}$} & Control & $\begin{array}{l}\text { - Difficult } \\
\text { - Consume a lot of time to solve } \\
\text { - Need to refer to the notes frequently } \\
\text { - Need to refer to the teacher frequently } \\
\text { - Need to discuss a lot with team members }\end{array}$ \\
\hline & Experimental & $\begin{array}{l}\text { - Difficult at the beginning } \\
\text { - Need to refer to the notes } \\
\text { - Need to refer to the teacher } \\
\text { - Need to critically think to solve problems } \\
\text { - Need to discuss with the team members }\end{array}$ \\
\hline \multirow[t]{2}{*}{$\begin{array}{l}\text { Students' perception on } \\
\text { the difficulty level of } \\
\text { the mini project }\end{array}$} & Control & $\begin{array}{l}\text { - Quite difficult } \\
\text { - Do not know the concept or theory should be used } \\
\text { - Do not understand the basic theories } \\
\text { - Difficult to relate between theories } \\
\text { - Need to refer to the notes frequently } \\
\text { - Need to refer to the teacher frequently }\end{array}$ \\
\hline & Experimental & $\begin{array}{l}\text { - Difficult } \\
\text { - Need to understand the basic theories } \\
\text { - Strong basic understanding } \\
\text { - Need to discuss with team members } \\
\text { - Refer to the notes } \\
\text { - Refer to the teachers } \\
\text { - Able to understand the relationship between theories }\end{array}$ \\
\hline \multirow[t]{2}{*}{$\begin{array}{l}\text { Impact of the teamwork } \\
\text { skills to the memory } \\
\text { retention }\end{array}$} & Control & $\begin{array}{l}\text { - Need help from team member to understand theory and } \\
\text { concept } \\
\text { - Need help from team member for each project } \\
\text { - Refer to the notes together with team members while } \\
\text { doing project. } \\
\text { - Less impact }\end{array}$ \\
\hline & Experimental & $\begin{array}{l}\text { - A lot of impact } \\
\text { - Teach the team member } \\
\text { - Easy to memorize while doing group discussion }\end{array}$ \\
\hline \multirow[t]{2}{*}{$\begin{array}{l}\text { Impact of the difficulty } \\
\text { level to the memory } \\
\text { retention }\end{array}$} & Control & $\begin{array}{l}\text { - A lot of impact } \\
\text { - Still unclear to use the theory in the practice } \\
\text { - Need notes and teacher guidance while doing difficult } \\
\text { task } \\
\text { - Difficult to differentiate between projects. }\end{array}$ \\
\hline & Experimental & $\begin{array}{l}\text { - A lot of impact } \\
\text { - Need a clear understanding of the theory } \\
\text { - Less referring to the notes because they are already } \\
\text { understood } \\
\text { - Able to differentiate between projects }\end{array}$ \\
\hline $\begin{array}{l}\text { Frequency of theory } \\
\text { application in the } \\
\text { project }\end{array}$ & Control & $\begin{array}{l}\text { - Less application } \\
\text { - Do not understand the theory they should use } \\
\text { - Difficult to see the theory should be used in the } \\
\text { practical } \\
\text { - Do not understand basic theory }\end{array}$ \\
\hline
\end{tabular}




\begin{tabular}{|c|c|c|}
\hline & Experimental & $\begin{array}{l}\text { - Apply basic theory frequently to the projects } \\
\text { - Need strong basic theory } \\
\text { - Able to see basic theory in the practical }\end{array}$ \\
\hline \multirow[t]{2}{*}{$\begin{array}{l}\text { Relationship between } \\
\text { each project }\end{array}$} & Control & $\begin{array}{l}\text { - Difficult to see the relationship between projects } \\
\text { - Difficult to differentiate between projects. } \\
\text { - Difficult to understand the theory integration in a } \\
\text { project }\end{array}$ \\
\hline & Experimental & $\begin{array}{l}\text { - Need time to understand theory integration } \\
\text { - Able to see the relationship between projects } \\
\text { - Able to apply basic concepts in each project }\end{array}$ \\
\hline \multirow[t]{2}{*}{$\begin{array}{l}\text { Impact of work manual } \\
\text { preparation to memory } \\
\text { retention }\end{array}$} & Control & $\begin{array}{l}\text { - Not effective } \\
\text { - Do without thinking } \\
\text { - Need to refer to the notes because they are not } \\
\text { understood the basic concepts } \\
\text { - Tend to forget due to no understanding }\end{array}$ \\
\hline & Experimental & $\begin{array}{l}\text { - No need detail work manual } \\
\text { - Not effective } \\
\text { - Do without thinking } \\
\text { - Do not challenge the thinking ability } \\
\text { - Less understanding }\end{array}$ \\
\hline
\end{tabular}

Based on the analysis through interviews, the control group acknowledged that they had difficulty remembering what they have learned because they did not fully understand the basic concepts or theories provided. Furthermore, the practical work they did initially did not require them to fully apply the knowledge they learned because they only needed to follow the procedure. In addition, they also had trouble in applying the knowledge they have learned as there is no or little correlation between one mini project and another mini project. For experimental groups, they recognized that PJBL able to help them to improve their retention of knowledge and skills for longer periods of time. This is due to the degree of difficulty in the mini projects and final projects given which require them to read the notes more often to understand the relevant theories at an early phase. The relationship between a mini project with another mini project is also important for them as they claim they can apply the knowledge they have learned over and over and cause them to remember the content of the lesson more easily. In addition, among the factors that led to the improvement of knowledge retention were the frequency of theoretical application of the practical processes and the use of practical work procedures. Students from the experimental group admit that they can remember better and longer if they are more often applying the knowledge they have learned in the practical process. In other cases, the students from the control group of the detailed procedures of practical work do not help them in improving the retention of knowledge as it does not require them to understand the basic concepts and theoretical applications to make the practice.

\section{DISCUSSION}

Based on the result from the pre-test and post-test, it has been proven that students from experimental group who have undergone PjBL have increased the retention of knowledge and skills. Most of the students from the experimental group can answer almost the entire questions correctly at the post-test level, although initially both groups had the same background of knowledge. Five factors that contributed to the improvement of knowledge and skills retentions have been identified as shown in Figure 1. The first factor is the frequency of application of the knowledge in the practical process. According to Barbalho et al. (2017), the retention of knowledge in student memory can be enhanced if the student can apply practical knowledge learned in the class. It is important to ensure students can understand what they are learning. If the theories are applied frequently, the memory regarding to that theories will become stronger. In other words, a person can transfer a knowledge of short-term memory to long-term memory through methods of repetition. In the PjBL, students need to apply the 
basic theories and concepts learned repeatedly as they need to ensure students can remember and understand them well. The importance of applying the theory to practice is considered to give a clear picture of what the student has taught (Dunlonsky et al., 2013). In addition, every mini project should have related to each other, where students have the opportunity to apply the theory repeatedly. Students also can understand the relationship between one theory and another.

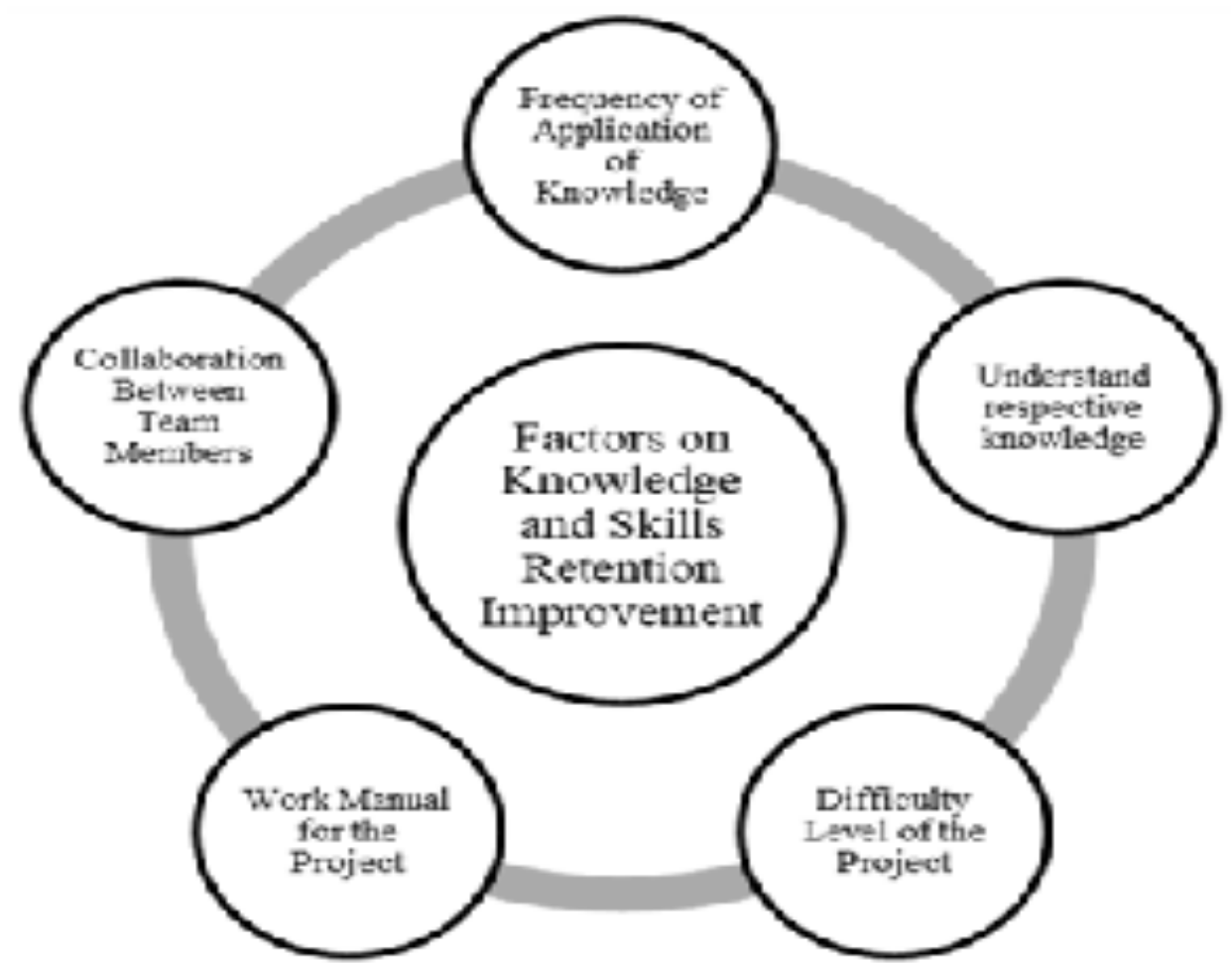

Figure 1. Factors that influence on knowledge and skills retention

The second factor is the understanding of the respective knowledge. Peterson and Djikic (2003) stated that a person would not be able to remember something if he did not understand it. Therefore, it is important to ensure that students understand each concept and theory taught in the class. Through $\mathrm{PjBL}$, students can apply what has been learned through various projects. At the same time, students are aware on how one theory is used in practical task. For technical subjects, an understanding of theory can be enhanced through practical work. PjBL is not only emphasizes students to make projects solely, but at the same time, PjBL also emphasizes on the aspects of theoretical understanding. Without proper theoretical understanding, practical work will not succeed and may even cause damage to the device or injury.

The third factor is the difficulty of the project. Based on Chistolini (2016), exposure of challenging work to students can enhance the retention of their knowledge and skills. He added, challenging work can teach them to seek initiative solutions and increase their motivation to learn. Projects provided to students undergoing PjBL are arranged from easy to difficult level. This is to enable them to train themselves with the problem-solving process. In addition, difficult projects or problems can improve the cognitive skills of the students as the projects allow them to try their best to understand the concepts and theories they have learned and to enable them to see the problem solving in a broader context. A complex and difficult problem-solving process was able to provide students with new inputs and knowledge that were not known before. This new knowledge is involved obtained through the integration of theories, where students need to combine several theories while solving the problems provided by $\mathrm{PjBL}$,

The fourth factor is the providing of work manual during the project. Undoubtedly, detailed manual handouts can help students to do their practical work. However, it cannot help students' cognitive development on lessons they have learned. This is due to the detailed practical manual handouts, 
students will not use their thinking skills to solve problems during practical task. According to Cheng et al. (2017), retention of knowledge is closely linked to the use of problem solving skills. When students use their thinking skills to solve problems, they will try to adopt all the knowledge and theories they have learned and try to relate them to the problems they face. Through PJBL, students are exposed to projects that require students to think critically to solve the problems they face. Furthermore, they were not given any manuals or work procedures which required them to seek their own based on the theory and knowledge they had learned. This process can enhance the cognitive skills of the students Dunlonsky (2013), as well as reinforcing their understanding and memory of something.

The fifth factor is the collaboration between team members. Working in one group will encourage students to communicate with each other during the problem-solving process. In addition, it also encourages students to share the knowledge they have learned from each other. In other words, students can exchange ideas and knowledge while doing a PjBL project. This will increase the retention of the students and skill. This process of knowledge transfer is a process in which students can teach other members of the group as well as receive input from other members of the group. Based on the revised Dale's Learning Cone by Hyland, $70 \%$ lessons learned will be remembered if students are involved in discussions between group members and teach what is known to others. PjBL also exposes students to real-world projects where it also gives students the advantage to remember that it can improve memory retention by $90 \%$.

\section{CONCLUSION}

Retention of knowledge and skills is an important aspect of being applied to potential teachers as they need that knowledge to teach students when they become teachers in school. Therefore, PjBL provides a good platform in improving the retention of knowledge and skills of the teacher. There are five factors that have been identified to assist the process. For improvement purposes, teaching methods other than PjBL should be identified to help students to improve their knowledge and skills. In addition, such studies should also be made to students from other fields such as Science, Mathematics, Literature and others which do not involve the elements of technical skills.

\section{ACKNOWLEDGEMENTS}

We would like express our gratitude to Ministry of Higher Education (MOHE) Malaysia and Universiti Teknologi Malaysia UTM for supporting this research for GUP Tier 2 (Vot. 13J93).

\section{REFERENCES}

Bajrami, L. (2015). Teacher's new role in language learning and in promoting learner autonomy. Procedia-Social and Behavioral Sciences, 199, 423-427.

Barbalho, S. C. M., Reis, A. C. B., Bitencourt, J. A., Leão, M. C. L. A., \& Silva, G. L. (2017). A project based learning approach for production planning and control: Analysis of 45 projects developed by students. Production, 27, 1-16.

Buddelmeyer, S. L. (1995). Hands-on versus verbal occupation: The effect on free recall in learning disabled children. Master thesis, Medical College of Ohio.

Cheng, S. C., She, H. C., \& Huang, L. Y. (2017). The impact of problem-solving instruction on middle school students' physical science learning: Interplays of knowledge, reasoning, and problem solving. Eurasia Journal of Mathematics, Science and Technology Education, 14(3), 731-743.

Chistolini, S. (2016). A project based learning curriculum promotes executive functioning skills in students. Master thesis, California State University Northridge.

Custers, E. (2010). Long-term retention of basic science knowledge: A review study. Advances in Health Science Education: Theory and Practice, 15(1), 109-128.

Dunlosky, J., Rawson, K. A., Marsh, E. J., Nathan, M. J., \& Willingham, D. T. (2013). Improving students' learning with effective learning techniques: Promising directions from cognitive and educational psychology. Psychological Science in the Public Interest, 14(1), 4-58.

Jamaliah, J. (2014). Kesediaan guru kolej vokasional dalam pengajaran amali teknologi elektronik di Negeri Pahang. Master thesis, Universiti Tun Hussein Onn Malaysia. 
Klemm, W. R. (2007). What good is learning if you don't remember it? Journal of Effective Teaching, 7(1), 61-73.

Mohd Yusof, H. (2014). Penilaian kemahiran employability dalam kalangan pelajar kejuruteraan politeknik di Semenanjung Malaysia. PhD thesis, Universiti Pendidikan Sultan Idris.

Muhammad Khair, N., Ahmad Nabil M. N., Dayana Farzeeha, A. \& Mohd Safarin, N. (2011). Problem-Based Learning (PBL) and Project-Based Learning (PJBL) in engineering education: A comparison. In Proceedings of the IETEC, pp. 1-14.

Paryono. (2017). The importance of TVET and its contribution to sustainable development. AIP Conference Proceedings, 1887(1), 1-14.

Peterson, J. B., \& Djikic, M. (2003). You can neither remember nor forget what you do not understand. Religion and Public Life, 33, 85-118.

Thomas, A. (2000). Development as practice in a liberal capitalist world. Journal of International Development, 12(6), 773-787.

Yoto. (2017). Preparing skilled labor in industry through production-based curriculum approach in vocational high school. AIP Conference Proceedings, 1887(1), 1-6. 